\title{
Increased level of tumor necrosis factor- $\alpha$ in patients with antiphospholipid syndrome: marker not only of inflammation but also of the prothrombotic state
}

\author{
Jakub Swadzba $\cdot$ Teresa Iwaniec $\cdot$ Jacek Musial
}

Received: 18 October 2009/Accepted: 29 November 2009/Published online: 15 December 2009

(C) Springer-Verlag 2009

\begin{abstract}
Connections between inflammation and thrombosis are intriguing, especially in a condition such as an antiphospholipid syndrome (APS), a disease characterized by immune-mediated thrombosis. Tumor necrosis factor alpha (TNF- $\alpha)$ is a cytokine which shares proinflammatory and prothrombotic actions, while a soluble form of interlukin-2 receptor (sIL-2R) is considered a typical marker of (auto)immune inflammation with not known direct links to thrombosis. The differences in the pathogenesis of APS as compared to other autoimmune diseases might be connected with different serum levels of both mediators. To answer this question, we studied 147 patients with systemic lupus erythematosus (SLE), 21 with SLE-like syndrome (SLE-LS), 20 with isolated APS (primary antiphospholipid syndrome, PAPS), and 32 healthy controls. Thirty-six patients from the SLE group fulfilled the updated APS criteria (secondary APS, SAPS). In comparison to healthy subjects, TNF- $\alpha$ concentration was increased in all patients, while sIL-2R rose significantly in the SLE group only. APS (both SAPS and PAPS) was characterized by the highest levels of TNF- $\alpha$. Moreover, patients with lupus anticoagulant or elevated levels of IgG anticardiolipin or IgG anti- $\beta_{2}$-glycoprotein I antibodies had higher TNF- $\alpha$ levels than patients without the presence of any type of antiphospholipid antibodies (aPL). In conclusion, the presence of aPL is associated with higher TNF- $\alpha$ level, whereas increased level of sIL-2R is rather
\end{abstract}

J. Swadzba ( $)$ - T. Iwaniec $\cdot$ J. Musial

Department of Medicine, Jagiellonian University Medical

College, Krakow, Poland

e-mail: swadzba@diag.pl connected with definite SLE where inflammatory processes prevail. It might be hypothesized that TNF- $\alpha$ plays a major role in pathogenesis of APS thrombotic phenomena.

Keywords TNF- $\alpha \cdot$ sIL-2R $\cdot$ Antiphospholipid syndrome $\cdot$ Inflammation $\cdot$ Thrombosis

\section{Introduction}

Antiphospholipid syndrome (APS) is an autoimmune disease which differs from most other systemic autoimmune diseases by its propensity to develop thrombosis. Systemic lupus erythematosus (SLE) is the prototypic example of an immune mediated, generalized inflammatory disease. Both diseases often occur together leading to the interplay between inflammatory and prothrombotic phenomena [1].

In general, systemic inflammation is a potent prothrombotic stimulus. Inflammatory mechanisms upregulate procoagulant factors, downregulate natural anticoagulants and inhibit fibrinolytic activity [2]. Endotoxin, tumor necrosis factor alpha (TNF- $\alpha$ ) and interleukin- $1 \alpha$ induce tissue factor (TF) expression, primarily on endothelial cells and monocytes/macrophages, promoting blood coagulation [3]. Activation of the complement C5b-C9 complex changes the cell surface to a more procoagulant phenotype by the shift of negatively charged phospholipids from the inner to the outer membrane [4]. Inflammatory reaction is also accompanied by the increase in fibrinogen and C-reactive protein (CRP) blood levels. CRP itself increases TF and decreases TF pathway inhibitor (TFPI) concentrations, what may be important in pathogenesis of arterial thrombosis and myocardial infarction [5]. Of the natural anticoagulants, protein $\mathrm{C}$ pathway appears to be the most strongly influenced by inflammation with thrombomodulin 
(TM) and the endothelial cell protein $\mathrm{C}$ receptor (EPCR) being both downregulated by TNF- $\alpha$ [6].

On the other hand, thrombotic processes enhance inflammatory reactions, mainly through the action of TF and thrombin [7]. Activation of platelets leads to the release of CD40 ligand, which, in turn, induces TF expression and increases IL-6 levels [8]. Thrombin also augments leukocyte adhesion and activation, stimulates endothelial cells to produce platelet activating factor and increases an expression of P-selectin [9].

A common inhibitory pathway for thrombosis and inflammation also exists. Activated protein C (APC) acting directly as an anticoagulant, functions also as an anti-inflammatory and cytoprotective agent through specific receptors: EPCR and protease activated receptor-1 (PAR-1) [10].

It is possible that TNF- $\alpha$ is a proinflammatory cytokine with the strongest prothrombotic action. TNF- $\alpha$ stimulates monocyte and neutrophil adhesion to endothelium, inhibits protein $\mathrm{C}$ system, impairs fibrinolysis and increases $\mathrm{TF}$ expression on the cell surface [2]. Produced mainly by activated monocytes, macrophages, and $\mathrm{T}$ lymphocytes, this cytokine has been found to be elevated in patients suffering from both, SLE [11] and APS [12]. We hypothesized that TNF- $\alpha$ might be more elevated in APS patients, with thrombosis as its prominent feature, than in those with other autoimmune diseases where immune-mediated inflammation prevails.

In contrast to TNF- $\alpha$, a possible role of soluble interleukin-2 receptor (sIL-2R) in thrombosis and prothrombotic states is unknown. Soluble IL-2R is a key marker of lymphocyte $\mathrm{T}$ activation, crucial for the regulation of an autoimmune inflammatory response [13]. Binding of interleukin-2 (IL-2) to its receptor on the surface of T-lymphocyte triggers a series of intracellular signaling events that result in the activation and proliferation of resting $\mathrm{T}$ cells. Upon activation of $\mathrm{T}$ cells, IL-2 receptor molecules are expressed on the surface and a soluble form is released. It has been found that autoimmune processes are associated with elevated levels of sIL-2R $[14,15]$.

We speculated that sIL-2R could be less elevated in an isolated form of APS, not associated with other autoimmune diseases, where inflammatory process is less (if at all) pronounced. If both, TNF- $\alpha$ and sIL-2R seem to be markers of autoimmune diseases, we asked whether their serum levels might correlate with the thrombotic state on one hand, and the intensity of autoimmune inflammation from the other. To answer this question, we have measured serum levels of both mediators in subjects with autoimmune diseases with or without presence of antiphospholipid antibodies (aPL) and examined carefully the differences which can be specific for patients fulfilling updated criteria for APS [16].

\section{Patients}

We studied 188 patients ( 165 women and 23 men, aged 18 72; mean age 40.5 years) referred to the Outpatient Clinic for Autoimmune Diseases in Jagiellonian University Medical College. SLE was diagnosed in 147 patients based on the presence of at least four American College of Rheumatology (ACR) criteria [17]. The group of SLE-like syndrome (SLE-LS), defined by the presence of 2 or 3 of these criteria including antinuclear antibodies, consisted of 21 cases. Thirty-six patients in the SLE group fulfilled recently revised APS classification criteria [16] (SAPS subgroup). There was no APS patient in the SLE-LS group. In 20 patients, APS was not accompanied by any features of another autoimmune disease (PAPS). The groups were not statistically different in terms of sex and age. The control group consisted of 32 healthy subjects, matched by sex and age with the group studied.

A detailed history (a uniform set of questions) was taken from all the patients by a trained physician. All available medical records were also carefully analyzed. Objective data confirming typical clinical involvement and laboratory test abnormalities of APS and SLE were required. All thrombotic episodes had to be confirmed by the imaging techniques (USG, CT and/or NMR). Pregnancy complications were defined according to recent updated APS classification criteria [16] and were confirmed by an experienced obstetrician based on available medical records.

From the total group of patients, 66 subjects suffered from thrombosis ( 45 venous, 17 arterial, and 4 both) and 42 women experienced pregnancy complications. Among 20 patients with PAPS, there were 15 cases of thrombosis (9 venous, 5 arterial, and 1 both) and nine cases of fetal loss (4 women had thrombosis and fetal loss). In the SAPS group 31 patients suffered from thrombosis (22 venous, 7 arterial, and 2 both) and 13 women suffered from pregnancy morbidity. Remaining cases of thrombosis $(n=20)$ and pregnancy complications $(n=20)$ appeared in patients with SLE or SLE-like syndrome without laboratory signs of APS.

The study was approved by the local ethical committee. All of the patients provided informed consent.

\section{Methods}

Lupus anticoagulant (LA) was detected in accordance with the three-step procedure recommended by the International Society on Thrombosis and Haemostasis (ISTH) [18]. We used partial thromboplastin time (PTT LA, Diagnostica Stago, France) and diluted Russell's viper venom time (DVV test, American Diagnostica, USA) for screening, and 
Staclot LA (Diagnostica Stago, France) and DVV Confirm (American Diagnostica, USA) for confirmation. Tests were run on Behring Coagulation Timer (BCT) and Fibrintimer analyzers (Siemens, Germany).

Serum levels of anticardiolipin (aCL) and anti- $\beta_{2}$-glycoprotein I $\left(\mathrm{a} \beta_{2} \mathrm{GPI}\right)$ antibodies (both of IgG and IgM classes) were measured using an in-house ELISA [19]. Following the recent suggestions [20, 21], monoclonal antibodies HCAL and EY2C9 (Sapporo Standards) against $\beta_{2}$ GPI were used as calibrators for the construction of standard curves for IgG and IgM, respectively [22]. All the aPL measured values exceeding 99 percentile of a healthy control group were considered positive, if confirmed by a second determination at least 12 weeks apart.

Serum concentrations of TNF- $\alpha$ and sIL-2R were determined by an immunoenzymatic method using commercially available kits on Immulite 1000 chemiluminescence automatic analyzer (Siemens, Germany). According to the manufacturer, reference ranges for healthy population are lower than $8.1 \mathrm{pg} / \mathrm{ml}$ for $\mathrm{TNF}-\alpha$ and below $710 \mathrm{U} / \mathrm{ml}$ for sIL-2R.

Mann-Whitney test was used for statistical analysis. Correlation of variables was assessed by means of Spearman's rank correlation coefficient.

\section{Results}

Among our patients, LA was found in 38 subjects, aCL IgG in 79 , aCL IgM in 57, a $\beta_{2}$ GPI IgG in 36 , and a $\beta_{2}$ GPI IgM in 40 subjects. Altogether, at least one aPL at a level fulfilling the revised APS classification criteria (at least two measurements exceeding 99 percentile, at least 12 week apart) was found in 93 patients.

Serum concentration of TNF- $\alpha$ was significantly elevated in all groups of patients (SLE, SLE-LS and PAPS) as compared to controls. The highest levels of TNF- $\alpha$ were found in patients with PAPS, followed by these from the SAPS subgroup. In the SLE group, patients fulfilling APS classification criteria had significantly higher TNF- $\alpha$ levels than the remaining patients suffering from SLE (Table 1).

Levels of sIL-2R were also higher in patients than in controls but the difference reached statistical significance for SLE group only. There were no differences in sIL-2R levels between studied groups of patients. Some trend toward higher levels of sIL-2R in SLE as compared to SLE-LS $(P=0.06)$ and PAPS $(P=0.07)$ patients could be seen. Interestingly, there was also a trend to the lower levels of sIL-2R in the PAPS group as compared to those with SAPS $(P=0.06)$ (Table 1$)$.

When aPL-positive patients (regardless of the concomitant presence of clinical APS symptoms) were compared to aPL-negative ones, higher $\mathrm{TNF}-\alpha$ values (but not
Table 1 TNF- $\alpha$ and sIL2-R levels in the groups studied

\begin{tabular}{llll}
\hline $\begin{array}{l}\text { Groups } \\
\text { studied }\end{array}$ & $\begin{array}{l}\text { Number of } \\
\text { patients }(n)\end{array}$ & $\begin{array}{l}\text { TNF- } \alpha \\
(\mathrm{pg} / \mathrm{ml})\end{array}$ & $\begin{array}{l}\text { sIL2-R } \\
(\mathrm{U} / \mathrm{ml})\end{array}$ \\
\hline SLE & 147 & $13.3 \pm 7.2^{\mathrm{a}, \mathrm{c}}$ & $789 \pm 591^{\mathrm{a}}$ \\
SAPS & 36 & $15.1 \pm 7.3^{\mathrm{a}, \mathrm{c}, \mathrm{d}}$ & $779 \pm 396^{\mathrm{a}}$ \\
SLE-APS- & 111 & $12.7 \pm 7.1^{\mathrm{a}}$ & $791 \pm 635^{\mathrm{a}}$ \\
SLE-LS & 21 & $9.8 \pm 4.2^{\mathrm{a}, \mathrm{b}}$ & $559 \pm 224$ \\
PAPS & 20 & $16.6 \pm 9.8^{\mathrm{a}}$ & $569 \pm 190$ \\
Controls & 32 & $7.7 \pm 2.3$ & $427 \pm 143$ \\
\hline
\end{tabular}

Results are expressed as mean \pm standard deviation (SD)

${ }^{\text {a }} P<0.05$ versus controls

${ }^{\mathrm{b}} P<0.05$ versus PAPS

c $P<0.05$ versus SLE-LS

${ }^{\mathrm{d}} P<0.05$ versus SLE-APS

Table 2 TNF- $\alpha$ and sIL2-R levels in patients with and without aPL

\begin{tabular}{llll}
\hline $\begin{array}{l}\text { Group of } \\
\text { patients }\end{array}$ & $\begin{array}{l}\text { Number of } \\
\text { patients }(n)\end{array}$ & $\begin{array}{l}\mathrm{TNF} \alpha \\
(\mathrm{pg} / \mathrm{ml})\end{array}$ & $\begin{array}{l}\text { sIL2-R } \\
(\mathrm{U} / \mathrm{ml})\end{array}$ \\
\hline All patients & 188 & & \\
aPL+ & 93 & $14.8 \pm 11.6^{\mathrm{a}}$ & $789 \pm 660$ \\
aPL- & 95 & $11.7 \pm 5.8$ & $692 \pm 392$ \\
SLE group & 147 & & \\
aPL+ & 63 & $14.9 \pm 8.3^{\mathrm{a}}$ & $907 \pm 778^{\mathrm{a}}$ \\
aPL- & 84 & $12.0 \pm 6.0$ & $709 \pm 409$
\end{tabular}

Results are expressed as mean $\pm \mathrm{SD}$

a $P<0.05$ aPL + versus aPL-

sIL-2R) were seen in the former. Inside the SLE group, these differences were evident for both markers (Table 2).

Further analysis showed that the levels of TNF- $\alpha$ also depended on the type of aPL. TNF- $\alpha$ was higher in patients showing the presence of LA or ACL IgG or a $\beta_{2}$-GPI IgG antibodies as compared to those without any antibodies (Fig. 1). A weak, but significant correlation between aCL IgG and TNF- $\alpha$ levels $(r=0.31 ; P=0.0001$; by Spearman rank test) was found.

The presence of the APS clinical criteria (thrombosis and pregnancy complications) were associated with a tendency toward the elevation of TNF- $\alpha$. However, this difference did not reach statistical significance (data not shown).

The levels of cytokines were also analyzed in relation to historical presence of symptoms and signs of SLE (Table 3). Elevated levels of sIL-2R were associated with many SLE clinical symptoms, whereas TNF- $\alpha$ was significantly elevated in SLE patients with only renal involvement. As far as immunologic criteria of SLE is considered, patients with the presence of ds-DNA antibodies as well as those with decreased $\mathrm{C} 4$ concentrations showed higher values of both cytokines. 

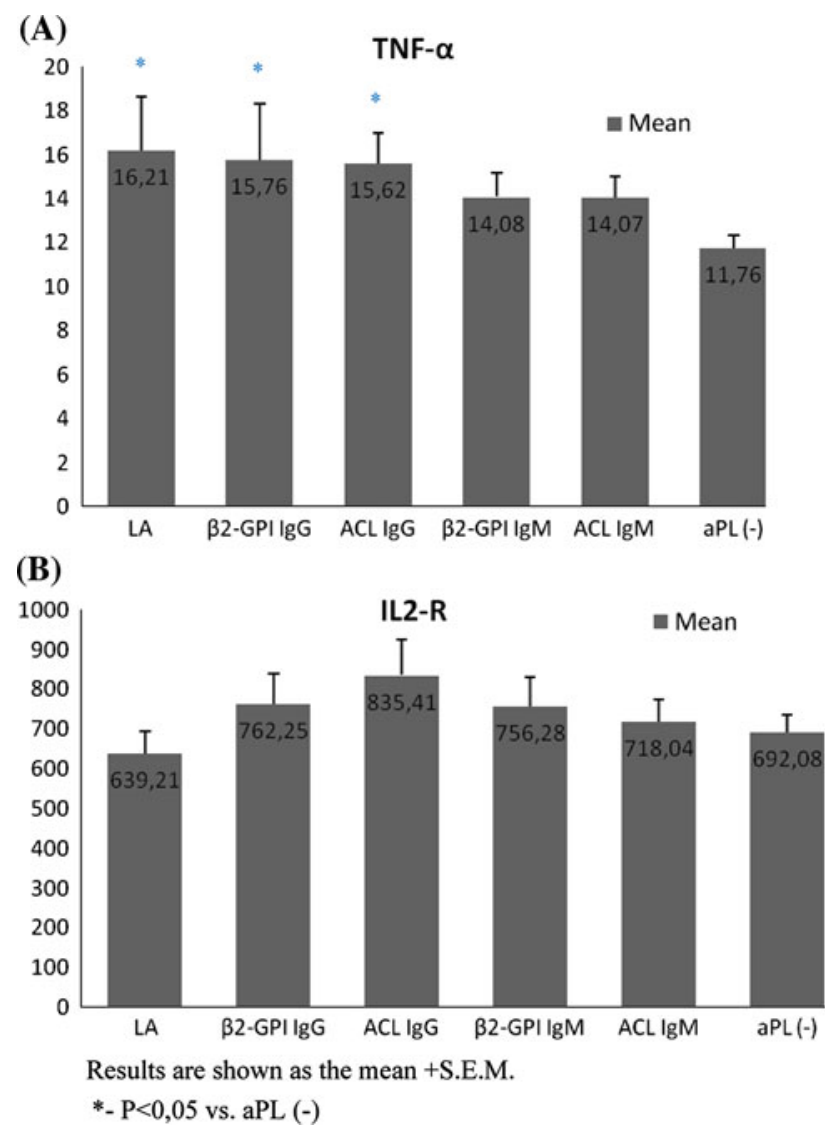

Fig. 1 Levels of TNF- $\alpha$ (a) and sIL2-R (b) depending on the presence and the type of aPL. Results are shown as the mean + SEM $[* P<0.05$ versus aPL $(-)]$

\section{Discussion}

In our study, we have shown that: (a) elevated levels of TNF- $\alpha$ are present not only in SLE but also in PAPS patients and (b) whilst the highest levels of TNF- $\alpha$ were detected in patients with APS (PAPS and SAPS), sIL-2R levels were more elevated in SLE patients, especially within those showing symptoms and signs related to the generalized inflammatory reaction.

In SLE group of patients, elevation of both markers and their association with disease activity has already been shown $[11,12,14,15,23]$. We support these findings by showing that patients with an active disease (decreased $\mathrm{C} 4$ levels, presence of ds-DNA autoantibodies and renal involvement) had significantly higher levels of TNF- $\alpha$ and sIL-2R than the others. Recently, it was published that in PAPS patient higher level of TNF- $\alpha$ is connected with lower level of $\mathrm{C} 3$ and $\mathrm{C} 4$ and lupus anticoagulant activity [24]. Patients showing other clinical symptoms (arthritis, serositis and skin involvement) show only elevated sIL-2R levels (Table 3). It may be hypothesized that this is due to the fact that sIL-2R is a more sensitive marker of inflammation than TNF- $\alpha$.
Levels of sIL-2R in SLE-LS and PAPS patients (negligible widespread inflammation) were not different from the controls (Table 1). Possibly in these groups of patients, lymphocyte $\mathrm{T}$ activation and inflammatory reactions are much less pronounced than in fully blown SLE. In this respect, the PAPS group seems to be interestingly showing highest levels of TNF- $\alpha$ and a relatively low levels of sIL$2 \mathrm{R}$. Our data may suggest that sIL-2R is a good marker of autoimmune activity but it does not reflect prothrombotic state, typical for APS.

In contrast, serum TNF- $\alpha$ was especially elevated in patients diagnosed with definite APS (Table 1) and those with antiphospholipid antibodies (Table 2). Our results corroborate with those of Bertolaccini et al. [25], who showed elevated TNF- $\alpha$ levels in patients with APS. Also, in accordance with our findings, they were unable to show any differences between its primary and secondary form (Table 1). It may indicate that elevated TNF- $\alpha$ levels are related rather to pathogenesis of thrombosis, common for both forms of APS, than to inflammation-very limited in PAPS. However, such a causal relation between TNF- $\alpha$ and thrombosis is not uniformly accepted. In the experimental setting it has been shown that TNF- $\alpha$ might exert antiplatelet and antithrombotic activity [26].

TNF- $\alpha$ was found to be higher in patients positive for LA or aPL of the IgG class than in those with IgM antibodies. These LA or IgG-positive patients showed significantly higher levels of TNF- $\alpha$ as compared to aPL-negative group (Fig. 1). These findings indirectly strengthen the notion about the important pathogenic role of LA and $\mathrm{IgG}$ aPL (as opposed to IgM) in the development of APSrelated thrombosis [27]. If eventually proven, it could also serve as yet another argument in the discussion about the negligible clinical significance of IgM aPL in APS [28, 29].

It has been suggested that TNF- $\alpha$ plays an important role in inducing APS-related pregnancy loss [30], and thrombosis $[12,31]$. However, in our study, we were unable to find any significant differences in TNF- $\alpha$ levels between patients with and without APS clinical symptoms. This is not surprising as there were usually wide temporal gaps between TNF- $\alpha$ determinations and clinical complications which took place in the distant past.

High level of TNF- $\alpha$ was rather connected with the present level of aPL than with the historical events of thrombosis. In future, hopefully, prospective studies can answer the question which groups of patients have the highest risk of getting thrombosis.

Several studies indicate that aPL [32,33] and TNF- $\alpha$ [34] can activate endothelium and induce prothrombotic phenotype of endothelial cells, leading to increased thrombin generation. Endothelial cell activation causes in vivo up-regulation of the TF which has been proposed as a main potential mechanism of APS-related thrombosis [35, 36]. 
Table 3 TNF- $\alpha$ and sIL2-R levels in patients with and without SLE symptoms and signs

\begin{tabular}{|c|c|c|c|c|c|}
\hline SLE symptoms and signs & $n$ & TNF- $\alpha$ & $P$ & IL-2R & $P$ \\
\hline \multicolumn{6}{|l|}{ Skin SLE criteria } \\
\hline+ & 107 & $13.66 \pm 7.27$ & NS & $846.01 \pm 657$ & 0.0008 \\
\hline- & 81 & $12.74 \pm 11.4$ & & $598.08 \pm 262$ & \\
\hline \multicolumn{6}{|l|}{ Arthritis } \\
\hline+ & 150 & $13.04 \pm 7.28$ & NS & $783.5 \pm 590$ & 0.01 \\
\hline- & 38 & $14.15 \pm 13.12$ & & $583.94 \pm 238$ & \\
\hline \multicolumn{6}{|l|}{ Serositis } \\
\hline+ & 29 & $13.94 \pm 8.17$ & NS & $877.2 \pm 506$ & 0.01 \\
\hline- & 159 & $13.07 \pm 9.56$ & & $697.25 \pm 540$ & \\
\hline \multicolumn{6}{|l|}{ Renal disorder } \\
\hline+ & 69 & $14.62 \pm 8.05$ & 0.02 & $864.37 \pm 718$ & 0.01 \\
\hline- & 119 & $12.48 \pm 9.85$ & & $655.35 \pm 353$ & \\
\hline \multicolumn{6}{|l|}{ Neurologic disorder } \\
\hline- & 24 & $14.07 \pm 8.87$ & NS & $762.22 \pm 408$ & NS \\
\hline- & 164 & $13.15 \pm 9.34$ & & $733.92 \pm 557$ & \\
\hline \multicolumn{6}{|l|}{ Haematologic disorder } \\
\hline+ & 128 & $13.48 \pm 10.03$ & NS & $705.09 \pm 372$ & NS \\
\hline- & 60 & $12.79 \pm 7.43$ & & $813.4 \pm 793$ & \\
\hline \multicolumn{6}{|l|}{ Anti-Sm } \\
\hline+ & 9 & $16.17 \pm 5.97$ & NS (0.06) & $1,198 \pm 756$ & 0.01 \\
\hline- & 179 & $13.12 \pm 9.39$ & & $716.25 \pm 517$ & \\
\hline \multicolumn{6}{|l|}{ Anti-RNP } \\
\hline+ & 24 & $15.1 \pm 7.75$ & NS (0.07) & $1,034.54 \pm 1,114$ & NS \\
\hline- & 164 & $12.99 \pm 9.46$ & & $688.75 \pm 347$ & \\
\hline \multicolumn{6}{|l|}{ Anti-Ro } \\
\hline+ & 84 & $12.95 \pm 6.54$ & NS & $859.74 \pm 716$ & 0.01 \\
\hline- & 104 & $13.52 \pm 11.01$ & & $634.13 \pm 276$ & \\
\hline \multicolumn{6}{|l|}{ Anti-La } \\
\hline+ & 60 & $12.71 \pm 6.6$ & NS & $845.02 \pm 770$ & NS \\
\hline- & 128 & $13.52 \pm 10.29$ & & $686.77 \pm 371$ & \\
\hline \multicolumn{6}{|l|}{ Anti-dsDNA } \\
\hline+ & 53 & $15.65 \pm 7.8$ & 0.0004 & $855.11 \pm 432$ & 0.001 \\
\hline- & 135 & $12.33 \pm 9.64$ & & $692.84 \pm 567$ & \\
\hline \multicolumn{6}{|l|}{ C4 decreased level } \\
\hline+ & 33 & $16.37 \pm 10.09$ & 0,04 & $1063.36 \pm 1041$ & 0.04 \\
\hline- & 155 & $12.6 \pm 8.98$ & & $675.12 \pm 341$ & \\
\hline
\end{tabular}

Once endothelial cells become activated, up-regulation of TF may be further augmented by a synergistic effect of TNF- $\alpha$ and factor Xa [37]. Other changes typical for this prothrombotic phenotype include increased expression of adhesion molecules (ICAM-1, VCAM-1, selectins E and P) [38, 39], and formation of endothelial microparticles [40]. Raschi et al. have shown that anti-beta ${ }_{2}$ GPI antibodies induce translocation of $\mathrm{NF} \kappa \mathrm{B}$ in a manner similar to that elicited by LPS and TNF- $\alpha$. Anti-beta ${ }_{2}$ GPI antibodies bind to beta ${ }_{2}$ GPI autoantigen, which acts as a toll-like receptor, and induce activation of endothelium via the MyD88 pathway [41]. The other proposed mechanism for aPLinduced TF expression is the phosphorylation of p38 mitogen-activated protein kinase (MAPK) in endothelial cells and/or platelets [42, 43].

It is not clear whether aPL acts on endothelial cells directly or (as is the case with LPS) through TNF- $\alpha$. The latter possibility finds support in the article of DunoyerGeindre et al. [44]. Independently from the mechanism, prothrombotic state, typical for APS, seems to be associated with both markedly elevated levels of aPL and increased concentrations of TNF- $\alpha$.

Our results suggest that while sIL-2R seems to be a good marker of a generalized (auto)immune inflammation, TNF$\alpha$ might be crucial to the prothrombotic action of pathogenic aPL antibodies. If confirmed, it would offer an 
intriguing possibility of using TNF-alpha blockade as a therapeutic option in APS.

\section{References}

1. Hoffman M, Monroe DM, Roubey RAS (2001) Links between the immune and coagulation systems: how do "antiphospholipid antibodies" cause thrombosis? Immunol Res 22:109-116

2. Esmon CT (2003) Inflammation and thrombosis. J Thromb Haemost 1:1343-1348

3. Bevilaqua MP, Pober JS, Majeau GR, Fiers W, Cotran RS, Gimbrone MA (1986) Recombinant tumor necrosis factor induces procoagulant activity in cultured human vascular endothelium: characterization and comparison with the actions of interleukin 1. Proc Natl Acad Sci USA 83:4533-4537

4. Sims PJ, Faioni PM, Wiedmer T, Shattil SJ (1988) Complement proteins C5b-9 cause release of membrane vesicles from the platelet surface that are enriched in the membrane receptor for coagulation factor Va and express prothrombinase activity. J Biol Chem 263:18205-18212

5. Wu J, Stevenson MJ, Brown JM, Grunz EA, Strawn TL, Fay WP (2008) C-reactive protein enchances tissue factor expression by vascular smooth muscle cells. Arterioscler Thromb Vasc Biol 28:698-704

6. Conway EM, Rosenberg RD (1988) Tumor necrosis factor suppresses transcription of the trombomodulin gene in endothelial cells. Mol Cell Biol 8:5588-5592

7. Chu AJ (2005) Tissue factor mediates inflammation. Arch Biochem Biophys 400:123-132

8. Miller DL, Yaron R, Yellin MJ (1998) CD40L-CD40 interaction regulate endothelial cell surface tissue factor and thrombomodulin expression. J Leukoc Biol 63:373-379

9. Pierangeli SS, Espinola RG, Liu X, Harris EN (2001) Thrombogenic effects of antiphospholipid antibodies are mediated by intracellular adhesion molecule-1, vascular cell adhesion molecule-1 and P-selectin. Circ Res 88:245-250

10. Crawley JTB, Efthymiou M (2008) Cytoprotective effect of activated protein C: specificity of PAR-1 signaling. J Thromb Haemost 6:951-953

11. Studnicka-Benke A, Steiner G, Petera P, Smolen JS (1996) Tumour necrosis factor alpha and its soluble receptors parallel clinical disease and autoimmune activity in systemic lupus erythematosus. Br J Rheumatol 35:1067-1074

12. Forastiero RR, Martinuzzo ME, de Larranaga GF (2005) Circulating levels of tissue factor and proinflamatory cytokines in patients with primary antiphospholipid syndrome or leprosy related antiphospholipid antibodies. Lupus 14:129-136

13. Rubin LA (1990) The soluble interleukin-2 receptor: biology function and clinical application. Ann Intern Med 113:619-627

14. Wolf RE, Brelsford WG (1988) Soluble interleukin-2 receptors in systemic lupus erythematosus. Arthritis Rheum 31:729-735

15. Neish C, Charley M, Fertig N, Medsger T, Deng JS (1993) Elevated serum soluble interleukin-2 receptor levels in subacute cutaneus lupus erythematosus. J Dermatol Sci 5:143149

16. Miyakis S, Lockshin MD, Atsumi T, Branch DW, Brey RL, Cervera R, Derksen RHWM, de Groot PG, Koike T, Meroni PL, Reber G, Shoenfeld Y, Tincani A, Vlachoyiannopoulos PG, Krilis SA (2006) International consensus statement on an update of the classification criteria for definite antiphospholipid syndrome (APS). J Thromb Haemost 4:295-306
17. Hochberg MC (1997) Updating the American College of Rheumatology revised criteria for the classification of systemic lupus erythematosus. Arthritis Rheum 40:1725

18. Brandt JT, Triplett DA, Alving B, Scharer I (1995) Criteria for the diagnosis of lupus anticoagulants: an update. Thromb Haemost 74:1185-1190

19. Swadźba J, de Clerck LS, Stevens WJ, Bridts CH, van Cotthem KA, Musial J, Jankowski M, Szczeklik A (1997) Anticardiolipin antibodies, anti- $\beta 2$-glycoprotein I, antiprothrombin antibodies and lupus anticoagulant in patients with systemic lupus erythematosus with a history of thrombosis. J Rheumatol 24:1710-1715

20. Ichikawa K, Tsutsumi A, Atsumi T, Matsuura E, Kobayashi S, Hughes GR, Khamashta MA, Koike T (1999) A chimeric antibody with the human gammal constant region as putative standard for assays to detect IgG beta2-glycoprotein I-dependent anticardiolipin and anti-beta2-glycoprotein I antibodies. Arthritis Rheum 42:2461-2470

21. Wong RCW (2004) Consensus guidelines for anticardiolipin antibody testing. Thromb Res 114:559-571

22. Swadźba J, Sanak M, Iwaniec T, Dziedzina S, Musiał J (2006) Valine/leucine 247 polymorphism of $\beta 2 \mathrm{GPI}$ in patients with antiphospholipid syndrome: lack of association with anti- $\beta 2 \mathrm{GPI}$ antibodies. Lupus 15:218-222

23. Davas EM, Tsirogianni A, Kappou I, Karamitsos D, Economidou I, Dantis PC (1999) Serum IL-6, TNF $\alpha$, p55 srTNF $\alpha$, p75 $\operatorname{srTNF} \alpha$, srIL- $2 \alpha$ levels and disease activity in systemic lupus erythematosus. Clin Rheumatol 18:17-22

24. Oku K, Atsumi T, Bohgaki M, Amengual O, Kataoka H, Horita T, Yasuda S, Koike T (2009) Complement activation in patients with primary antiphospholipid syndrome. Ann Rheum Dis 68:1030-1035

25. Bertolaccini ML, Atsumi T, Lanchbury JS, Caliz AR, Katsumata K, Vaughan RW, Kondeatis E, Khamashta MA, Koike T, Hughes GRV (2001) Plasma tumor necrosis factor $\alpha$ levels and the-238*A promoter polymorphism in patients with antiphospholipid syndrome. Thromb Haemost 85:198-203

26. Cambien B, Bergmeier W, Saffaripour S, Mitchell, Wagner DD (2003) Antithrombotic activity of TNF- $\alpha$. J Clin Invest 112:1589-1596

27. Swadzba J, Iwaniec T, Szczeklik A, Musial J (2007) Revised classification criteria for antiphospholipid syndrome and the thrombotic risk in patients with autoimmune diseases. J Thromb Haemost 5:1883-1889

28. Galli M, Reber G, de Moerloose P, de Groot PG (2008) Invitation to a debate on the serological criteria that define the antiphospholipid syndrome. J Thromb Haemost 6:399-401

29. Swadzba J, Musiał J (2009) More on: the debate on antiphospholipid syndrome classification criteria. J Thromb Haemost 7:501-502

30. Berman J, Girardi G, Salmon JE (2005) TNF-alpha is a critical effector and a target for therapy in antiphospholipid antibodyinduced pregnancy loss. J Immunol 174:45-90

31. Tanne D, Katzav A, Beilin O, Grigoriadis NC, Blank M, Pick GG, Landenberg P, Shoenfeld Y, Chapman J (2008) Interaction of inflammation, thrombosis, aspirin and enoxaparin in CNS experimental antiphospholipid syndrome. Neurobiol Dis 30:56-64

32. Musiał J, Swadźba J, Jankowski M, Grzywacz M, Bazan-Socha S, Szczeklik A (1997) Thrombin generation measured ex vivo following microvascular injury is increased in SLE patients with antiphospholipid-protein antibodies. Thromb Haemost 78:1173-1177

33. Pierangeli S, Harris EN (2003) Probing antiphospholipid mediated-thrombosis: the interplay between anticardiolipin antibodies and endothelial cells. Lupus 12:539-545

34. Speiser W, Kapiotis S, Kopp CW, Simonitsch I, Jilma B, Jansen B, Exner M, Chott A (2001) Effect of intradermal tumor necrosis 
factor- $\alpha$-induced inflammation on coagulation factors in dermal vessel endothelium. Thromb Haemost 85:362-367

35. Amengual O, Atsumi T, Khamashta MA, Hughes GRV (1998) The role of the tissue factor pathway in the hypercoagulable state in patients with the antiphospholipid syndrome. Thromb Haemost 79:276-281

36. Lopez-Pedrera Ch, Buendia P, Aguirre MA, Velasco F, Cuadraro MJ (2006) Anthiphospholipid syndrome and tissue factor: a thrombotic couple. Lupus 15:161-166

37. Hezi-Yamit A, Wong PW, Bien-Ly N, Komuves LG, Prasad KSS, Phillips DR (2005) Synergistic induction of tissue factor by coagulation factor Xa and TNF: evidence for involvement of negative regulatory signaling cascades. Proc Natl Acad Sci USA 102:12077-12082

38. Kaplanski G, Cacoub P, Fernarier C, Marin V, Gregoire R, Gatel A, Durand JM, Harle JR, Bongrand P, Piette JC (2000) Increased soluble vascular cell adhesion molecule- 1 concentrations in patients with primary or systemic lupus erythematosusrelated antiphospholipid syndrome: correlations with the severity of thrombosis. Arthritis Rheum 43:55-64

39. Espinola RG, Liu X, Colden-Stanfield M, Hall J, Harris EN, Pierangeli SS (2003) E-selectin mediates pathogenic effects of antiphospholipid antibodies. J Thromb Haemost 1:843-848
40. Combes V, Simon AC, Grau GE, Arnoux D, Camoin L, Sabatier F, Mutin M, Sanmarco M, Sampol J, Dignat-George F (1999) In vitro generation of endothelial microparticles and possible prothrombotic activity in patients with lupus anticoagulant. J Clin Invest 104:93-102

41. Raschi E, Testoni C, Bosisio D, Borghi MO, Koike T, Mantovani A, Meroni PL (2003) Role of the MyD88 transduction signaling pathway in endothelium activation by antiphospholipid antibodies. Blood 101:3495-3500

42. Vega Ostertag M, Casper K, Swerlick R, Ferrara D, Harris EN, Pierangeli SS (2005) Involvement of p38 MAPK in the up-regulation of tissue factor on endothelial cells by antiphospholipid antibodies. Arthritis Rheum 52:1545-1554

43. Bohgaki M, Atsumi T, Yamashita Y, Yasuda S, Sakai Y, Furusaki A, Bohgaki T, Amengual O, Amasaki Y, Koike T (2004) The p38 mitogen-activated protein kinase (MAPK) pathway mediates induction of the tissue factor gene in monocytes stimulated with human monoclonal anti $\beta 2$ GPI antibodies. Int Immunol 16:16331641

44. Dunoyer-Geindre S, de Moerlose P, Galve-de Rochemonteix B, Reber G, Kruithof EK (2002) $\mathrm{NF} \kappa \mathrm{B}$ is an essential intermediate in the activation of endothelial cells by anti-beta 2 -glycoprotein 1 antibodies. Thromb Haemost 88:851-857 